\title{
Prebiotic Effect of Different Cereal Bran (Sorghum, Barely and Millet) on Growth of Bifidobacterium longum BB536 during Fermentation of Goat Milk
}

\author{
Limia Hashim Mohamed, Barka Mohammed Kabeir*, \\ Salma Elghali Mustafa and Salma Elzen Ibraheem
}

\author{
*Department of Food Science and Technology, College of Agricultural Studies \\ Sudan University of Science and Technology, Khartoum, Sudan
}

*Corresponding author

\begin{tabular}{l} 
K e y w o r d s \\
Cereal bran, \\
Prebiotic, \\
Bifidobacterium, \\
Goat milk, \\
Fermentation \\
\hline Article Info \\
Accepted: \\
07 September 2020 \\
Available Online: \\
10 October 2020
\end{tabular}

\section{A B S T R A C T}

\section{Introduction}

The growing interest in health and diet has recently produced the concept of functional foods. By definition, functional foods are normal foods and parts of the daily diet, but they contain a component that benefits some particular physiological function and reduce the risk of diseases (Salovaaro, 1999). Nowadays, the wide applications of 
functional food are in form containing probiotics and non-digestible carbohydrate known as prebiotics (Fuller and Gibson, 1997).

Reorganization of probiotic effect dates back to the $19^{\text {th }}$ century when the French scientist Louis Pasteur (1822 - 1895) postulated the importance of microorganisms in human life, this was further reinforced by work done by 1908 Nobel Prize-winner Elie Metchnikoff, which led to the concept of probiotics. Strain of Bifidobacterium, lactobacillus and nonpathogenic yeast such as Saccharomyces boulardii are principally used individually or in combination as probiotics (Tomasik and Tomasik, 2003). Bifidobacteria is the predominant species of human colonic and faces microbiota. It has been extensively introduced in the food industry and pharmaceutical applications (Guarner and Malagelada, 2003).

Bifidobacterium longum is one of the bifidobacteria species found mainly in human faeces and it may be considered as the most common species of bifidobacteria, being found both in infant and adult. Potential benefits from consumption of $B$. longum include: antagonistic action toward intestinal pathogens, improved lactose utilization, anticarcinogenic action and control of serum cholesterol levels. Scientific studies showed the benefits offered by Bifidobacterium longum BB536 (Kojima et al., 1996; Namba et al., 2003). Thus there is considerable interest in incorporating these healths promoting bifidobacteria into food. However, most human origin probiotics are fastidious when used alone, they are characterized by low growth capability in food mediums including the dairy, the main a recommended carrier of probiotics to human (FAW/WHO, 2001). Thus, scarcity of animal milk in many countries makes it difficult to provide a adequate bifidobacteria intake.
Dietary carbohydrates and soluble fiber that are able to stimulate, specifically the growth of potentially beneficial bacteria, e.g., bifidobacteria at the expense of the more harmful pathogenic microorganisms, are called prebiotics. Presence of prebiotics in the colon helps to modify the microflora in such a way that the health-promoting bacteria like bifidobacteria and lactobacilli become predominant in numbers and may be accompanied by elimination of pathogenic bacteria (Kouane et al., 2005).

Dietary fibers are often characterized by high nutritional quality, as they are able to cure many chronic diseases and improve texture, sensory characteristics, and shelf life of foods. The fast growing food industry will likely generate an ever-growing amount of byproducts including bran, husk, peel, pomace, and other products that are rich in dietary fibers (Betoret et al., 2011). Therefore, finding optimal use of dietary fibers becomes increasingly imperative. In this respect, the exploration of prebiotic effect for different Sudanese cereal bran is lacking. Therefore, the objective of this study is to evaluate the growth of B. longum BB536 in goat milk supplemented with cereal bran and evaluate its related physiochemical changes during fermentation process.

\section{Materials and Methods}

\section{Raw materials}

Inulin was obtained from A natural Product Company (London, England). Different cereal bran (sorghum, barley and millet) were purchased from a local crops market at central market in Bahri (Khartoum state, Sudan). Goat fresh milk was obtained from the animal farm at Department of Animal Production, College of Agricultural Studies, Sudan University of Science and Technology (Khartoum, Sudan). 


\section{Preparation of cereal bran}

Different cereal bran were ground and sieved using appropriate mesh. The resulting powder stored in a dark polyethylene bag at freezer until used.

\section{Preparation of fermentation inoculums}

B. longum BB536 was obtained from the stock culture of microbiology laboratory (Department of Food Science Technology, Collage of Agriculture Studies (SUST). The strain was maintained at $-20{ }^{\circ} \mathrm{C}$ in $20 \%$ glycerol solution. Stock culture was prepared by activation of the strain in skim milk, incubation an aerobically at $37{ }^{\circ} \mathrm{C}$ for $24 \mathrm{~h}$. The obtained culture was reactivated again under the same conditions to prepare enough stock for the experiment. The working culture was prepared by twice successive transformations of stock culture in $10 \%$ sterilized skim milk $\left(121^{\circ} \mathrm{C}\right.$ for $\left.15 \mathrm{~min}\right)$ and incubation at $37^{\circ} \mathrm{C}$ for $24 \mathrm{~h}$.

\section{Growth medium and fermentation conditions}

Growth medium were formulated from goat milk supplemented with $1 \%$ inulin or different cereal bran (sorghum, barely and millet). Formulated medium were sterilized $\left(121^{\circ} \mathrm{C}\right.$ for $\left.15 \mathrm{~min}\right)$ and inoculated with a $3 \%$ active culture working of $B$. longum BB536 followed by incubation at $37{ }^{\circ} \mathrm{C}$ for $24 \mathrm{~h}$.

\section{Enumeration of viable $B$. longum BB536 cell}

MRS medium was used to enumerate $B$. longum BB536 of different fermented products using the plate count technique. Fermented samples were drawn at initial and every $6 \mathrm{~h}$ intervals during fermentation. $1 \mathrm{ml}$ of fermentation broth was diluted in peptone water, followed by plating on Demann Rogosa agar (MRS) supplement with $0.05 \%$ L-cystiene. The plates were incubated unaerobically at $37{ }^{\circ} \mathrm{C}$ for $48 \mathrm{~h}$. The growth was calculated as Colony Forming Unit per $\mathrm{ml}(\mathrm{CFU} / \mathrm{ml})$.

\section{Determination of titrable acidity}

The titrable acidity (TA) of the different fermented products was determined according to AOAC method (2006). Ten ml of sample were weighted into a conical flask. A distilled water was added until the volume in the flask was $150 \mathrm{ml}$. The sample was then vigorously agitated and filtered. Twenty five milliliters of the filtrate were pipetted into porcelain dish, five drops of phenolphthalein added, and the sample was titrated against $0.1 \mathrm{~N} \mathrm{NaOH}$ till a fain pink colour that lasted for at least 30 seconds was obtained; then acidity of different products was calculated.

\section{Determination of total soluble solids (TSS)}

Total soluble solids (TSS) of the fermented products were determined at room temperature using digital refractometer with degree $\mathrm{Brix}^{\mathrm{o}}$ scale 0-100 according to AOAC (1990) method.

\section{Determination of $\mathrm{pH}$ value}

The $\mathrm{pH}$ value of the different fermented products was determined using a $\mathrm{pH}$-meter (model HI 8521 microprocessor bench $\mathrm{PH} / \mathrm{MV} / \mathrm{C}$ meter, Romania). Two standard buffer solution of $\mathrm{pH} 4.00$ and 7.00 were used for calibration of the $\mathrm{pH}$ meter at room temperature. The $\mathrm{pH}$ meter was allowed to stabilize for one minute and then the $\mathrm{pH}$ of the fermented products samples was directly measured.

\section{Chemical composition}

\section{Determination of moisture content}

Moisture was determined according to the modified method of AOAC (1990). Five 
grams of the sample was weight using in sensitive balance, after weighting the empty dishes and then transferred to an oven (KatNR.2851, Electrohelios, Sweden) at $105 \pm$ $0.1{ }^{\circ} \mathrm{C}$ for 6 hours .Afterwards, the dish with sample was transferred to dessicator and allow to cool to room temperature before reweighting to calculated moisture.

\section{Determination of fat content}

Fat content was determined according to the official method of AOAC (1990). A sample of $5 \mathrm{~g}$ was weighed in extraction thimble and covered with cotton, and then extracted with hexane. The thimble containing the sample and a pre-dried weight sample and flask containing about $100 \mathrm{ml}$ hexane was attached to the extraction unit. The extraction process was conducted for $16 \mathrm{~h}$. At the end of the extraction period, the flask was disconnected from the unit and the solvent was evaporated. Later, the flask with the remaining crude hexane extracted was put in an oven, cooled to room temperature reweight and the dried extract was registered as fat content.

\section{Determination of protein content}

Protein content of different fermented products was determined by Kjeldhal method according to the AOAC (1990) method.

\section{Ash content}

The ash content of the sample was determined according to the AOAC (1990) method. Two grams of the deferent fermented products were weighed into a clean dry porcelain crucible and placed in muffle furnace (model Tipoforon Z A No 18203 Get Ran 1002. England) at $600^{\circ} \mathrm{C}$ for 6hours. The Crucible was transferred to a desiccator, cooled to room temperature and weighed to calculate ash content.

\section{Determination of crude fiber}

Two gram of a defatted sample was placed into a conical flask containing $200 \mathrm{ml}$ of $\mathrm{H}_{2} \mathrm{SO}_{4}(0.26 \mathrm{~N})$. The flask was fitted to a condenser and allowed to boil for 30 minutes. At the end of the digestion period, the flask was removed and the digestate was filtered through a proclaim filter crucible (No.3). After that, the precipitate was repeatedly rinsed with distilled boiled water followed by boiling in $200 \mathrm{ml} \mathrm{NaOH}(0.23)$ solution for 30 min under reflux condenser and the precipitate was filtered . Rinsed with hot distilled water, 20ml ethyl alcohol (96\%) and $20 \mathrm{ml}$ diethyl ether. Finally, the crucible was dried at $105^{\circ} \mathrm{C}$ until a constant weight was obtained and the difference in weight was considered a crude fiber.

\section{Calculation of carbohydrates}

Carbohydrates were calculated by difference according to the following:

Total carbohydrates $=100 \%-[$ Moisture $(\%)$ + Protein $(\%)+$ Fat $(\%)+$ fiber $(\%)$ and Ash $(\%)$.

\section{Determination of minerals}

Potassium (K) and calcium (Ca) were determined by flame photometer (Sherwood Flame Photometer i410, Sherwood Scientific Ltd. Cambridge, UK) according to procedure of AOAC (1990). The knob of flame photometer was adjusted to potassium and calcium respectively and reading was set to zero using deionized water. Blank solution was run and read again the set zero. Standard solution of each mineral was run and recorded the reading of flame photometer. The reading of potassium and calcium in products sample was obtained by running the sample one by one. Standard solution was run after each product sample. The standard curves were 
obtained by plotting absorbance values of standards against appropriate concentrations of elements. One gram of dried product samples was subjected to wet digestion method as described by Richards (1968). Then analysis was carried out spectrophotometer absorption (Varian AA 240, Victoria, Australia) to determine $\mathrm{Mg}$ and $\mathrm{Na}$ via a standard curve. To determine phosphorus content of products, colorimetric estimation method was used as described by (Kitson and Mellon, 1944).

\section{Statistical analysis}

One- way ANOVA and two sample paired tests were performed to examine significant differences between normally distributed data of replicated independent runs. Probability level of less than 0.05 was considered significant $(\mathrm{p}<0.05)$. All data were analyzed using vision 17 MINITAB statistical software for windows (2010).

\section{Results and Discussion}

Proximate composition of inulin and different cereal bran (sorghum, barley and millet)

As revealed in Table 1, inulin recorded the highest level of fiber and carbohydrate in comparison with other types of cereal bran. Thus inulin is an excellent source of prebiotic. Among cereal bran barley contained the highest level of fiber, followed by sorghum and them millet barn. Together with varying carbohydrate contents, all cereal bran might have prebiotic properties. In addition, they are good source of protein, fat and ash (Table 1).

Minerals content of inulin and different cereal bran (sorghum, barley and millet)

Table 2 showed that minerals content of different fiber such as Inulin recorded the highest levels in $\mathrm{Ca}, \mathrm{K}, \mathrm{Mg}$ and $\mathrm{Na}$; except the $\mathrm{P}$. Inulin contained the lowest $\mathrm{P}$ as compared to its level in cereal bran. All cereal bran contained small amount of $\mathrm{Ca}, \mathrm{K}, \mathrm{Mg}$ and $\mathrm{Na}$ (Table 2).

\section{Chemical composition of Bifidobacterium} longum BB536 fermented goat milk supplemented with $1 \%$ of different types of fiber*

There was no significant $(\mathrm{p}<0.05)$ difference in moisture and carbohydrate content at initial fermentation and maximum strain BB 536 growth of each specific fermented product (Table 3). Whereas, level of fat in inulin and sorghum bran fermented goat milk at initial and maximum growth were significant $(\mathrm{p}<0.05)$. However, ash content was only significant $(\mathrm{p}<0.05)$ between the initial and maximum growth in sorghum bran supplemented goat milk fermented with strain BB536. Similarly, fiber content was only significant $(p<0.05)$ between the initial and maximum growth in millet bran supplemented goat milk fermented with strain BB536 (Table $3)$.

The growth of Bifidobacterium longum BB536 during fermentation of goat milk supplemented with inulin and different cereal bran

Comparative growth of B. longum BB536 cultured during fermentation of goat milk supplemented with inulin and different cereal bran was shown in Table 4. There were significant $(\mathrm{p}<0.05)$ increases in strain $B B 536$ viable count by extended fermentation period in all type of fermented goat milk, as compared to strain level at beginning of fermentation. The maximum growth of the strain in all type of fermented products was attained at $12 \mathrm{~h}$ incubation. These high viable count of strain BB536 $\left(7.53 \pm 0.16^{\mathrm{b}}\right.$ $\left.8.43 \pm 0.03^{\mathrm{c}} \mathrm{Log} \mathrm{CFU} / \mathrm{ml}\right)$ in all fermented goat milk products exceed the minimum number ( 6 $\log \mathrm{CFU} / \mathrm{ml}$ fermented products) required to 
presence in probiotic food (Viderola and Reinheimer, 2000).

The rate of strain BB536 increases in different fermented goat milk were 2.57, 2.31, 1.93 and $1.18 \log \mathrm{CFU} / \mathrm{ml}$ in fermented products supplemented with sorghum bran, inulin, millet bran and barely bran, respectively. These rates of increases induced by different cereal bran are comparable to the prebitication (support growth of strain BB 536) with the commercial prebiotic. Therefore, tested cereal bran might have prebiotic effect on strain BB536. On the hand, the variations in growth rate of strain $B B 536$ could be attributed to variances in availability of nutrients required for growth in the different formulated products. In fact, goat milk contains almost the essential nutrient for strain growth. Together with different fiber combination could complement the nutrient component demand for strain BB 536 growth in formulated goat milk medium.

However, after maximum growth (12 h) the strain started to decline in all types of fermented goat milk products (Table 4). The decline of the strain might be due to the accumulation of acids or reduction of availability of nutrient required for the growth as stated by Kabeir et al., (2005) during fermentation of Sudanese thin porridge Medida. In spite of the continuous declining in viable count of strain $B B 536$ in all types of fermented goat milk up to $24 \mathrm{~h}$ incubation, the remained viable counts still above the number required to presence in probiotic food which is at least $6 \log \mathrm{CFU} / \mathrm{ml}$ fermented products (Viderola and Reinheimer, 2000).

pH changes during strain BB536 fermentation of goat milk supplemented with inulin and different cereal bran

During fermentation process with strain BB536 there were significant $(\mathrm{P}<0.05)$ decreases in $\mathrm{pH}$ levels of all types of formulated goat milk by extended fermentation period to $24 \mathrm{~h}$ (Table 5). The decreases in $\mathrm{pH}$ are due to increased acids production during fermentation process as a result of fermented sugar by strain $B B 536$; which produces acetic and lactic acid (De Vries et al., 1967). Moreover, the accumulated acids produced by Bifidobacterium strain, reported to have antibacterial activity such as prevention of the proliferation of pathogens (Bullen et al., 1976). The rate of $\mathrm{pH}$ decreases at maximum strain BB536 growth (12h incubation) were $1.82,1.07,0.67$ and $0.49 \mathrm{pH}$ in fermented goat milk supplemented with barely bran, inulin, millet bran and sorghum bran, respectively (Table 5). Level of acidity increased by extended fermentation period and thus caused reduction in $\mathrm{pH}$.

TSS changes during strain BB536 fermentation of goat milk supplemented with inulin and different cereal bran

Table 6 showed the changes in total soluble solid (TSS) during fermentation of different formulated goat milk with strain BB 536. There were significant $(\mathrm{P}<0.05)$ decreases in TSS levels in all types of fermented goat milk product by extended fermentation period to $24 \mathrm{~h}$. The rates of TSS decreases at maximum strain BB 536 growth (12h incubation) were $1.7,1.25,0.95$ and 0.75 in fermented goat milk with supplemented with barely bran, sorghum bran, millet bran and inulin, respectively. Enzymatic activity of the strain plays a vital role in rate of TSS reduction. The strain utilized soluble solid for energy source, particularly reducing suger the main components of TSS. Reductions in TSS by fermentation with B. longum BB536 and other probiotic strains were reported by Ibraheem et al., (2015), Kabeir et al., (2005), Badahdah et al., (2019) and Muyanj et al., (2010). 
Table.1 Proximate composition of inulin and different cereal bran (sorghum, barley and millet)*

\begin{tabular}{|c|c|c|c|c|}
\hline \multirow[t]{2}{*}{ Components (\%) } & \multicolumn{4}{|c|}{ Types of fiber } \\
\hline & Inulin & Sorghum bran & Barley bran & Millet bran \\
\hline Moisture & $3.000 \pm 0.00$ & $68.48 \pm 0.332$ & $50.15 \pm 0.156$ & $68.71 \pm 0.290$ \\
\hline Fat & ND & $3.125 \pm 1.039$ & $4.935 \pm 0.679$ & $5.935 \pm 0.0212$ \\
\hline Proteins & ND & $12.60 \pm 2.97$ & $13.915 \pm 1.110$ & $11.375 \pm 1.237$ \\
\hline Fiber & $89.00 \pm 0.00$ & $6.490 \pm 0.297$ & $19.685 \pm 0.870$ & $4.635 \pm 0.346$ \\
\hline Ash & ND & $2.425 \pm 0.0212$ & $8.660 \pm 0.0141$ & $3.190 \pm 0.283$ \\
\hline Carbohydrates & $8.000 \pm 0.000$ & $6.870 \pm 0.354$ & $2.640 \pm 0.156$ & $6.140 \pm 0.0849$ \\
\hline
\end{tabular}

$*$ Values are mean \pm SD for replicate independent analysis

$\mathrm{ND}=$ Not determined

Table.2 Mineral content of inulin and different cereal bran (sorghum, barley and millet)*

\begin{tabular}{|c|c|c|c|c|}
\hline \multirow{2}{*}{$\begin{array}{c}\text { Components } \\
(\mathbf{m g} / \mathbf{1 0 0 g})\end{array}$} & Inulin $^{\mathrm{a}}$ & Sorghum bran & Barley bran & Millet bran \\
\hline $\mathbf{C a}$ & $1.62 \pm 0.03^{\mathrm{a}}$ & $0.08 \pm 0.01^{\mathrm{b}}$ & $0.08 \pm 0.00^{\mathrm{b}}$ & $0.08 \pm 0.00^{\mathrm{b}}$ \\
\hline $\mathbf{K}$ & $0.76 \pm 0.01^{\mathrm{a}}$ & $0.11 \pm 0.01^{\mathrm{b}}$ & $0.10 \pm 0.00^{\mathrm{b}}$ & $0.09 \pm 0.01^{\mathrm{b}}$ \\
\hline $\mathbf{M g}$ & $0.82 \pm 0.02^{\mathrm{a}}$ & $0.03 \pm 0.00 \mathrm{c}$ & $0.02 \pm 0.00^{\mathrm{c}}$ & $0.05 \pm 0.21^{\mathrm{b}}$ \\
\hline $\mathbf{N a}$ & $1.74 \pm 0.00^{\mathrm{a}}$ & $0.11 \pm 0.13^{\mathrm{b}}$ & $0.02 \pm 0.06^{\mathrm{c}}$ & $0.02 \pm 0.00^{\mathrm{c}}$ \\
\hline $\mathbf{P}$ & $0.26 \pm 0.00^{\mathrm{b}}$ & $1.16 \pm 0.01^{\mathrm{a}}$ & $1.01 \pm 0.02^{\mathrm{a}}$ & $1.06 \pm 0.35^{\mathrm{a}}$ \\
\hline
\end{tabular}

$*$ Values are mean \pm SD for replicate independent runs.

$* *$ Values that bear different superscript letter in the same raw of are significantly different at $p<0.05$.

Table.3 Chemical composition of Bifidobacterium longum BB536 fermented goat milk supplemented with $1 \%$ of different types of fiber*

\begin{tabular}{|c|c|c|c|c|c|c|c|c|}
\hline \multirow{3}{*}{ Component } & \multicolumn{8}{|c|}{ Bifidobacterium longum BB536 fermented goat milk with different types of fiber } \\
\hline & \multicolumn{2}{|c|}{ Inulin } & \multicolumn{2}{|c|}{ Sorghum bran } & \multicolumn{2}{|c|}{ Barley bran } & \multicolumn{2}{|c|}{ Millet bran } \\
\hline & Initial & $\operatorname{Max}$ & Initial & Maximum & Initial & Maxim & Initial & Maximum \\
\hline Moistur & $86.9 \pm 0.01^{\mathrm{a}}$ & $86.77 \pm 0.04^{\mathrm{a}}$ & $88.54 \pm 0.01$ & $88.50 \pm 0.28^{\mathrm{a}}$ & $84.55 \pm 0.00^{\mathrm{a}}$ & $86.46 \pm 0.00^{\mathrm{a}}$ & $85.28 \pm 0.02^{\mathrm{a}}$ & $85.79 \pm 0.01^{\mathrm{a}}$ \\
\hline $\begin{array}{c}\text { Fat content } \\
(\%)\end{array}$ & $2.37 \pm 0.007^{\mathrm{d}}$ & $2.42 \pm 0.03^{\mathrm{e}}$ & $1.97 \pm 0.01^{\mathrm{e}}$ & $2.54 \pm 0.03^{c}$ & $1.840 \pm 0.00^{\mathrm{e}}$ & $2.015 \pm 0.00^{\mathrm{e}}$ & $2.32 \pm 0.028^{\mathrm{e}}$ & $2.44 \pm 0.02^{\mathrm{e}}$ \\
\hline $\begin{array}{c}\text { Protein } \\
\text { content }(\%)\end{array}$ & 0 & 2.56 & $2.59 \pm$ & $2.66 \pm$ & $2.62 \pm 0.00^{c}$ & $2.75 \pm 0.00^{c}$ & $2.52 \pm 0.00^{c}$ & 2.7 \\
\hline $\begin{array}{c}\text { Ash content } \\
(\%)\end{array}$ & $1.44 \pm 0.02^{f}$ & 1.84 & $1.54 \pm 0.01^{\mathrm{f}}$ & 1.76 & $1.55 \pm 0.00^{f}$ & $1.64 \pm 0.01^{\mathrm{f}}$ & $1.77 \pm 0.01^{\mathrm{f}}$ & $1.85 \pm 0.01^{\mathrm{f}}$ \\
\hline $\begin{array}{c}\text { Carbohydrates } \\
(\%)\end{array}$ & $13.06 \pm 0.01^{\mathrm{b}}$ & $13.23 \pm 0.04^{b}$ & $11.46 \pm 0.01^{b}$ & $11.51 \pm 0.28^{b}$ & $15.46 \pm 0.00^{b}$ & $13.56 \pm 0.01^{b}$ & $14.73 \pm 0.02^{b}$ & $14.21 \pm 0.01^{b}$ \\
\hline Fiber(\%) & $3.86 \pm 0.01^{\mathrm{c}}$ & $3.71 \pm 0.01^{\mathrm{c}}$ & $2.97 \pm 0.01^{\mathrm{c}}$ & $2.87 \pm 0.04^{c}$ & $2.40 \pm 0.00^{\mathrm{d}}$ & $2.02 \pm 0.01^{\mathrm{d}}$ & $2.62 \pm 0.02^{\mathrm{d}}$ & $2.60 \pm 0.00^{c}$ \\
\hline
\end{tabular}

$*$ Values are mean \pm SD for replicate independent runs.

**Values that bear different superscript letter in the same raw of each specific products are significantly different at $\mathrm{p}<0.05$. 
Table.4 The viable count of Bifidobacterium longum BB536 (log CFU/ml) during fermentation of goat milk supplemented with different types of fiber*

\begin{tabular}{|c|c|c|c|c|}
\hline \multirow{2}{*}{\begin{tabular}{c}
\multirow{2}{*}{$\begin{array}{c}\text { Fermented } \\
\text { time(h) }\end{array}$} \\
\cline { 2 - 5 }
\end{tabular}} & \multicolumn{4}{|c|}{ Fermented goat milk supplemented with different types of fiber } \\
\hline $\mathbf{0}$ & $5.52 \pm 0.32^{\mathrm{c}}$ & $5.86 \pm 0.06^{\mathrm{d}}$ & $6.07 \pm 0.03^{\mathrm{c}}$ & $6.03 \pm 0.1^{\mathrm{d}}$ \\
\hline $\mathbf{6}$ & $7.33 \pm 0.01^{\mathrm{b}}$ & $6.07 \pm 0.09^{\mathrm{c}}$ & $6.99 \pm 0.01^{\mathrm{b}}$ & $6.31 \pm 0.42^{\mathrm{c}}$ \\
\hline $\mathbf{1 2}$ & $7.53 \pm 0.16^{\mathrm{a}}$ & $8.43 \pm 0.03^{\mathrm{a}}$ & $7.65 \pm 0.06^{\mathrm{a}}$ & $7.96 \pm 0.02^{\mathrm{a}}$ \\
\hline $\mathbf{1 8}$ & $7.39 \pm 0.01^{\mathrm{b}}$ & $7.25 \pm 0.06^{\mathrm{b}}$ & $7.84 \pm 0.08^{\mathrm{a}}$ & $7.25 \pm 0.22^{\mathrm{b}}$ \\
\hline $\mathbf{2 4}$ & $7.30 \pm 0.06^{\mathrm{b}}$ & $6.93 \pm 0.17^{\mathrm{ab}}$ & $6.79 \pm 0.06^{\mathrm{b}}$ & $6.83 \pm 0.15^{\mathrm{bc}}$ \\
\hline
\end{tabular}

$*$ Values are mean \pm SD for replicate independent runs.

** Values that bear different superscript letter in the same column are significantly different at $\mathrm{p}<0.05$.

Table.5 pH changes during strain BB536 fermentation of goat milk supplemented with inulin and different cereal bran

\begin{tabular}{|c|c|c|c|c|}
\hline \multirow{2}{*}{$\begin{array}{l}\text { Fermented } \\
\text { time (h) }\end{array}$} & \multicolumn{4}{|c|}{ Fermented goat milk supplemented with different types of fiber } \\
\hline & Inulin & Sorghum bran & Barley bran & Millet bran \\
\hline $\mathbf{0}$ & $6.18 \pm 0.00^{\mathrm{a}}$ & $6.15 \pm 0.01^{\mathrm{a}}$ & $6.22 \pm 0.01^{\mathrm{a}}$ & $5.06 \pm 0.01^{\mathrm{a}}$ \\
\hline 6 & $6.04 \pm 0.01^{\mathrm{a}}$ & $6.01 \pm 0.04^{\mathrm{a}}$ & $4.95 \pm 0.00^{b}$ & $5.15 \pm 0.04^{\mathrm{a}}$ \\
\hline 12 & $5.11 \pm 0.00^{b}$ & $5.65 \pm 0.07^{b}$ & $4.40 \pm 0.00^{\mathrm{d}}$ & $4.45 \pm 0.00^{b}$ \\
\hline 18 & $5.01 \pm 0.01^{\mathrm{b}}$ & $5.47 \pm 0.01^{\mathrm{b}}$ & $4.81 \pm 0.00^{c}$ & $3.79 \pm 0.02^{c}$ \\
\hline 24 & $4.87 \pm 0.00^{c}$ & $4.51 \pm 0.01^{\mathrm{c}}$ & $4.61 \pm 0.00^{c}$ & $3.73 \pm 0.03^{c}$ \\
\hline
\end{tabular}

$*$ Values are mean \pm SD for replicate independent runs.

** Values that bear different superscript letter in the same column are significantly different at $p<0.05$.

Table.6 Total Soluble Solid during strain BB536 fermentation of goat milk supplemented with inulin and different cereal bran*

\begin{tabular}{|c|l|l|l|l|}
\hline \multirow{2}{*}{$\begin{array}{c}\text { Fermented } \\
\text { time (h) }\end{array}$} & \multicolumn{4}{|c|}{ Fermented goat milk supplemented with different types of fiber } \\
\hline & Inulin & Sorghum bran & Barley bran & Millet bran \\
\hline $\mathbf{0}$ & $8.30 \pm 0.21^{\mathrm{a}}$ & $7.45 \pm 0.07^{\mathrm{a}}$ & $8.20 \pm 0.14^{\mathrm{a}}$ & $9.55 \pm 0.07^{\mathrm{a}}$ \\
\hline $\mathbf{6}$ & $8.25 \pm 0.42^{\mathrm{a}}$ & $6.45 \pm 0.07^{\mathrm{b}}$ & $7.50 \pm 0.00^{\mathrm{b}}$ & $9.05 \pm 0.00^{\mathrm{b}}$ \\
\hline $\mathbf{1 2}$ & $7.55 \pm 0.07^{\mathrm{a}}$ & $6.20 \pm 0.14^{\mathrm{b}}$ & $6.50 \pm 0.00^{\mathrm{c}}$ & $8.60 \pm 0.14^{\mathrm{c}}$ \\
\hline $\mathbf{1 8}$ & $6.45 \pm 0.07^{\mathbf{b}}$ & $5.60 \pm 0.014^{\mathrm{c}}$ & $5.20 \pm 0.00^{\mathrm{d}}$ & $7.35 \pm 0.07^{\mathrm{d}}$ \\
\hline $\mathbf{2 4}$ & $5.90 \pm \mathbf{0 . 0 0}^{\mathbf{b}}$ & $4.45 \pm 0.21^{\mathrm{d}}$ & $4.99 \pm 0.16^{\mathrm{d}}$ & $6.25 \pm 0.07^{\mathrm{e}}$ \\
\hline
\end{tabular}

$*$ Values are mean \pm SD for replicate independent runs.

** Values that bear different superscript letter in the same column are significantly different at $\mathrm{p}<0.05$. 
Table.7 Titrable acidity (\%) during strain BB536 fermentation of goat milk supplemented with inulin and different cereal bran

\begin{tabular}{|c|c|c|c|c|}
\hline \multirow{2}{*}{$\begin{array}{c}\text { Fermented } \\
\text { time (h) }\end{array}$} & \multicolumn{4}{|c|}{ Fermented goat milk supplemented with different types of fiber } \\
\hline & Inulin & Sorghum bran & Barley bran & Millet bran \\
\hline $\mathbf{0}$ & $0.19 \pm \mathbf{0 . 0 0}$ & $0.24 \pm 0.07^{d}$ & $0.26 \pm 0.00^{\mathbf{e}}$ & $0.44 \pm 0.00^{\mathrm{c}}$ \\
\hline 6 & $0.22 \pm 0.01^{\mathrm{d}}$ & $0.20 \pm 0.00^{\mathbf{e}}$ & $0.75 \pm 0.01^{d}$ & $0.95 \pm 0.01^{\mathbf{b}}$ \\
\hline 12 & $0.65 \pm 0.07^{\mathrm{c}}$ & $0.44 \pm 0.01^{\mathrm{c}}$ & $0.82 \pm 0.00^{\mathbf{c}}$ & $0.93 \pm 0.01^{\mathrm{b}}$ \\
\hline 18 & $0.76 \pm 0.04^{b}$ & $0.62 \pm 0.01^{b}$ & $0.85 \pm 0.01^{b}$ & $0.94 \pm 0.02^{b}$ \\
\hline 24 & $0.81 \pm 0.00^{\mathrm{a}}$ & $0.73 \pm 0.00^{\mathrm{a}}$ & $0.92 \pm 0.07^{\mathbf{a}}$ & $1.02 \pm 0.01^{\mathrm{a}}$ \\
\hline
\end{tabular}

Titratable acidity during strain BB536 fermentation of goat milk supplemented with inulin and different cereal bran

Referring to the result in Table 7 it w), there were significant $(\mathrm{p}<0.05)$ increases in titratable acidity of different goat milk formulations by extended fermented period to 24h. Moreover, the rates of increase were $0.56,0.49,0.46$ and $0.2 \%$ at maximum growth of strain B. longum BB536 (12h) in fermented goat milk supplemented with barely bran, millet bran, inulin and sorghum bran, respectively. The increased acidity is explained by accumulation of acetic, lactic acid and other organic acids produced during fermentation of the formulated products (Sefa and Afoakwa, 2003). Similarly, acid increase due to fermentation were reported by many authors as a result of sugar fermentation (Ibraheem et al., (2015); Kabeir et al., (2005)

In conclusion, the chemical composition of different cereal bran revealed high levels of fiber, protein, fat that could contribute to improve the nutritional value of food. Together with goat milk of high nutritional cereal bran in one formula could produce complementary product provide nutritional benefits to consumers. On the other hand inulin was superior source of fiber, carbohydrate and minerals as compared to tested cereal bran. By fermentation and supplementation with inulin and different cereal bran, maximum growth of the strain BB 536 that fulfills the number required to presence in probiotic food was attained. Therefore, cereal bran could have prebiotic effect on strain BB 536 in goat milk medium for development of fermented functional food.

\section{References}

AOAC. (1990). Official Methods for Analysis (15th ed). Association of Official Analytical Chemists. Washington, D.C., USA.

Badahdah, BM Kabeir, SE Mustafa International Journal of Food , 2019 ijfans.org

Betoret, N Betoret, D Vidal, P Fito - Trends in Food Science \& Technology, 2011 Elsevier

Bullen, C.L., Tearle, P.V. and Willis, A.T. (1976). Bifidobacteria in the intestinal tract of infants: as in-vivo study. J Med Microbial. 9: 325- 333.

De Vries , W., Gerbrandy, S.H., Stouthamer, A.H.( 1967). Carbohydrate metabolism in Bifidobacterium bifidoium. Biochem. Biophys. Acta. 136, 415-422.

FAO (Food and Agriculture Organization). (2004). Rice is life. Italy: FAO. International Year of Rice "Rice and human nutrition" http://www.fao.Org/newsroom/en/focus/20 0346887/index.html. .

FAW/WHO reports of a joint FAW/WHO 
(2001). Export consultation on evaluation of health and nutritional properties of probiotics in food including powder milk with life lactic acid bacteria. American Cordoba Park Hotel .Cordoba .Argentina, $1-4$.

Fuller ,R . Gibson, G.R. (1997). Modification of the intestinal microflora using probiotics and probiotics. Scand. Journal of Gastoenterology 222,28S-31S.

Guarner, F., Malagelada, J.R. (2003). Gut flora in health and disease lancet 361. 512519.2.

Ibrahim, C Adams, A El-Zaart - JISTEMJournal of information, 2015 - SciELO Brazil.

Kabeir, B.M., Abd Aziz ,S. , Muhamed,, M. and Yazid. A.M. (2005). Growth of Bifidobacterium longum BB536 in Media (fermented cereal porridge) and their survival during storage. Let. Appl. Microbial., 41: 12-131.

Kitson, R.E., and Mellon, MG. (1944). Colorimetric determination of phosphorus as molybdivanadophosphoric acid. Ind. Eng. Chem. Anal. Ed.16:379-83.

Kojima, T., Yaeshima, T., Ishibashi, N., Shimamura, S., Hayasawa, H. (1996). Inhibitory effects of human-derived bifidobacterium on pathogenic Escherichia coli serotype O-111. Bioscience Microflora., 15(1): $17-22$

Kouane, D., Zhang, g., and Chen, J. 2005. Peanut milk and peanut milk based products production. A review. Critical Reviews in Food Science and Nutrition. 45:405-423.

MINITAB statistical software, Release 16 for windows, 2006, Minitab Inc, USA.
Muyanja, C., Birungi, S., Ahimbisibwe ,M., Semanda, J and Namugumya BS. (2010). Traditional processing, microbial and physicochemical changes during fermentation of Malwa. African Journal of Food, Agriculture, Nutrition and Development, Vol. 10, No. 10, pp.41244138 .

Namba , K., Yaeshima, T., Ishibashi, N., Hayasawa, H., Yamazaki, S. (2003). Inhibitory of Bifidobacterium longum on inter hemorrhagic Escherichia coli O157: H7. Bioscience Micro flora. 22: 85 - 91.

Richards, L.A. (1968). Diagnosis and improvement of saline and alkaline soil. $1^{\text {st }}$ Edn. IBH Publishing Co., New Delhi, India. Agri. Handbook No. 60.

Salovaara, H. (1999). Functional Foods : a global perspective. Cereal Food World. 44: 98.

Salunkhe, D.K. and S.S. Kadam. (1989). Handbook of World Food Legumes: Nutritional Chemistry, Processing Technology and Utilization. 1st Edn., CRC Press. Inc., Boca Raton.

Sefa-Dedeh, S., Cornelius, B., Amoa-Awua, W., Sakyi-Dawson, EO and Afoakwa, EO. (2003). The Microflora of Fermented Nixtamalized Corn. Int. J. Fd. Microbiol., 2755: 1-6.

Tomasik, P, J., Tomasic, P. (2003). Probiotics and probiotics. Cereal Chemistry 80, 113 117.

Viderola, C.G, Reinhelmer, J. (2000). A. Survival of probiotic microflora in Argentinian yoghurts during refrigerated storage. Food Research International; 33: 97-102.

\section{How to cite this article:}

Limia Hashim Mohamed, Barka Mohammed Kabeir, Salma Elghali Mustafa and Salma Elzen Ibraheem. 2020. Prebiotic Effect of Different Cereal Bran (Sorghum, Barely and Millet) on Growth of Bifidobacterium longum BB536 during Fermentation of Goat Milk. Int.J.Curr.Microbiol.App.Sci. 9(10): 625-634. doi: https://doi.org/10.20546/ijcmas.2020.910.074 